\title{
Explorative Study on Leadership Styles of Heads of the Public Technical Training Institutes in Bhutan
}

\author{
Sonam Wangmo
}

Ministry of Labour and Human Resources, Technical Training Institute-Thimphu, Bhutan

Received: 16 Nov 2020; Received in revised form: 03 Jan 2021; Accepted: 19 Jan 2021; Available online: 26 Jan 2021

(C)2021 The Author(s). Published by The Shillonga Publication. This is an open access article under the CC BY license (https://creativecommons.org/licenses/by/4.0/).

\begin{abstract}
The research is undertaken to ascertain leadership styles deployed by heads of public Technical Training Institutes (TTIs) in Bhutan. Quantitative research method was used for this study. A population of 160 staff members of six public TTIs was targeted where 122 staff members responded to the survey questionnaires. All the data were collected via Google Form and were analyzed with descriptive statistics.

The finding of the research revealed that democratic leadership style was most prevalent among the heads of public TTIs at high level with the mean score of 3.66. It was closely followed by laissez-faire leadership style with mean score of 3.58 at high-level. The least prevalent leadership style among the heads of public TTIs was found to be autocratic leadership style which scored moderate level with mean score of 3.27 .
\end{abstract}

Thus, it was concluded that heads of the public TTIs employed all types of classical leadership styles though at different level. An in-depth study on leadership styles of heads of public technical institutes in Bhutan with various variables is proposed for future researchers.

Keywords-autocratic, democratic, laissez-faire, leadership styles, technical training institutes (TTIs).

\section{INTRODUCTION}

\subsection{Research Background and the Rationale}

The art of leadership is as old as age itself stated Lucas and David (2008). But the style of leadership varied with time. Autocratic leadership style which was prevalent in medieval periods is being outshined by democratic leadership style that is found more popular today. Whatsoever the styles, leadership plays a significant and vital role in gearing society and organization in progression.

Wangmo (2013) asserted that "In educational institutions the importance of leadership is as crucial as in any organization for better performance and achieving the goals. Khata Jabor et al (2012) also cited that importance of leadership in technical and vocational education cannot be overemphasizing, for without proper leadership in Technical and Vocational Education and Training (TVET) programs, the goal to prepare people to be self-reliance will not be possible. In devoid of appropriate and efficient leadership styles of leaders, organizations will not succeed in achieving their goals despite the best policies and resources at hand. Wangmo (2013) stated that though organizations are fully prepared with necessary equipment, human resources and budgetary requirement, it will not be of any benefit if leaders are in deficit of leadership skills.

It is thought that one of the main problems in achieving organizational goals and satisfying the need of society in a developing country is capacity and effectiveness of leadership (Kedar \& Geleta, 2017). In Bhutan, societies put blames on TVET sector for not being able to meet ever-growing demand of skilled work force in the country (MoLHR, 2020). Despite receiving immense emphasis from the government due to the growing industrial scenarios, TVET sectors in Bhutan is yet to produce enough adept workers. The Royal Government of Bhutan (RGoB) has in the last decade invested significantly on the expansion of TVET to supply skilled and competent human capital in the country, and has initiated TVET reforms. It is clearly revealed in TVET Blue print 2016-2026 (MoLHR, 2016) that considerable progress has been made in setting up modern TVET system. Six Technical Training Institutes were established under Ministry of Labour and Human Resources (MoLHR) in the country to train youths on vocational skills. Though TVET was disregarded as a noteworthy player from academic angle, those declarations are 
gradually disregarded as many are conscious that TVET are the best providers of knowledge and skilled workers in the $21^{\text {st }}$ century (Ahmad, 2015).

As true to all organizations, the realization in achieving goals to yield skilled youth in TVET institutes will also depend to a large extend on its leadership. The aim to prepare individuals for self-reliance will not be feasible in absence of appropriate leadership in TVET. Thus, in TVET development perfect leadership is a must, reflected Khata Jabor et al (2012). Leadership and leaders are the pursuers of TVET successfulness suggested Brennan (2014). In fact, in Bhutan TVET was incepted as early as in 1961 with the commencement of First Five Year Plan (MoLHR, 2016). Despite its early commencement the progress in TVET system in Bhutan has lagged far behind for so many decades. The MoLHR developed TVET blue print 2016-2026 to uplift and revamp TVET system in Bhutan. The second pillar of the blue print framework stresses on "Improve Quality" issues that includes the managerial capacity within the TVET providers. And in the blue print it is also mentioned that more emphasis must be given to training and development of principals. This directly focuses on capacity building of the leadership of heads of TTIs in Bhutan.

Previously heads of the TTIs were appointed based on ability and experience of individuals in TVET field by concerned authority without having to undergo selection processes. However, the principal-ship recruitment process in TTIs was rationalized in 2016 with the implementation of TVET blue print 2016-2026, and thereafter principals (heads) in TTIs were recruited through open competition based on Bhutan Civil Servant Rules (BCSR), 2012 selection criteria since 2017.

Further, in effort to transform TVET, MoLHR has come up with TVET Statistics of Bhutan 2020 wherein quality training education and effective TVET governance are considered vital. Governance includes leadership. Popa (2012) expressed that leadership style and its factors have to be examined and adapted to new requirements for an organization to enhance its performance.

At this juncture no researchers or organizations seem to have carried out any study on leadership styles of the heads of TVET institutes in Bhutan. Thus, the researcher is motivated to explore types of prevalent leadership styles amongst the heads of public TTIs in Bhutan.

\subsection{Research Questions}

1.2.1. What are the leadership styles of head of public TTIs in Bhutan as perceived by their staff?

1.2.2. Which leadership style is the most prevalent amongst the head of public TTIs in Bhutan as perceived by their staff?

1.2.3. Which leadership style is the least prevalent amongst the head of public TTIs in Bhutan as perceived by their staff?

\subsection{Research Objectives}

1.3.1. To study the leadership styles of head of public TTIs in Bhutan as perceived by their staff.

1.3.2 To determine the most prevalent leadership styles amongst the head of public TTIs in Bhutan as perceived by their staff

1.3.3 To examine the least prevalent leadership styles amongst the head of public TTIs in Bhutan as perceived by their staff.

\subsection{Research Scope and Limitation}

The data were collected from six public TTIs located in various regions of Bhutan, and so, it had a wide range of research coverage. A total of 160 staff members in the selected institutes were the target population.

Despite the scope of mixed methodology, the study was limited to simple descriptive survey. The research site was confined to only six Public TTIs under MoLHR as they share the same situation, policies, medium of training delivery instructions and are under same administrative directives.

\subsection{Research Contributions}

The study provided clear understanding of leadership styles prevalent amongst the head of public TTIs in day-to-day administration and management of their institutes. The outcome could be used as benchmark or mechanism for policy enhancement in TVET system in the country. The findings are also expected to support authorities involved in monitoring institutes where special stress should be positioned on leadership programs that could yield better result. The result of research might motivate future researchers to identify variables that are dependent on leadership styles, and they can undertake further researches.

\section{LITERATURE REVIEW}

\subsection{Brief history of TVET institutes in Bhutan}

Modern education system was incepted in Bhutan in early 1960s with the launching of First Five-Year Plan (FFYP) in 1961, which was aimed to address the basic educational needs, and to develop human resources that were necessary for the nations' social and economic development (AES, 2012). As the FFYP implementation begun, Bhutan had heavily depended on skilled expatriates in accomplishment of the plan. The obligation to produce 
national skilled workforce thus had became imperative. So, the first TVET institute was established during the tenure of FFYP.

Don Bosco Technical School was established in 1965 at Rinchending (popularly known as Kharbandi), Phuenstholing to equip Bhutanese youths with modern technical skills. It was the first TVET institute in the country. Don Bosco Technical School was subsequently renamed as Royal Technical Institute (RTI). After a decade of establishing the first TVET institute, qualification up gradation prospects for finest graduates of Don Bosco was made accessible with the establishment of Royal Bhutan Polytechnic at Dewathang in 1974.

In 2003 RTI was bifurcated into four Vocational Training Institutes (VTIs) that were spread over several regions across the country. These institutes were VTI Chumey at Bumthang, VTI Khuruthang at Punakha, VTI Rangjung at Tashigang, and VTI Samthang at Wangdiphodrang.

The objectives these VTIs were to enhance accessibility to school leavers and unemployed youths in various corners of the country to get skilled for gainful employment in job markets. In 2007 another VTI institute was established at Sershong under Sarpang district. And in 2008 VTI Thimphu was set up at Luntenzampa in Thimphu. These six VTIs were later renamed as Technical Training Institutes (TTIs).

\subsection{Leadership Theories}

\subsubsection{Definition of Leadership and Leadership styles}

Leadership is a vast and broad term. "The term leadership is a complex concept which cannot have exact definition. It solely depends on how one perceives the leader in ones organization" specified Wangmo (2013). Stogdill (1974) stated that the definitions of leadership are various and as many as academicians who defined it. In fact, Rost (1991) found 221 leadership definitions from his extensive reading of 557 books.

Leadership is an interactive progression in between a leader and followers whereby leaders use authorities or influences to inspire and persuade followers to achieve organizational goals efficiently explained Kim (2010). Kusin (2015) defined leadership as ability of an individual to motivate, influence and enable others in successful and effective contribute in organization. Leadership is the process whereby leaders influence their followers in a way that they willingly strive towards achieving organizational goal specified Malechwanzi (2018). Although there are many leadership definitions, the sole responsibility of leadership remained the same, that is to take charge of an organization in accomplishing its goals.

Similar to leadership, leadership style cannot be singly connoted in unanimous. Its meaning and concept may vary from one individual to another depending on circumstances, and on how one comprehends leaders around them. The concept and definition of leadership style may differ from one person or one situation to another, mentioned Veliu et al (2017). Style is roughly equated to leader's behavior (Khan et al, 2015). Countless metaphors on leadership styles have been concluded by academicians like:

Oyetunji (2006) noted that "Leadership style is a way a leader leads." Nsubuga (2008) held it as "Modes or methods of leadership adopted by various leaders". Northouse (2007) defined it as the "Behavior pattern of a person who attempts to influence others". Despite numerous discoveries on denotation of leadership styles, its functional role on leaders are identical. As such, the researcher in this study defines leadership styles as a character portrayed by head of organization to gear subordinates towards organizational goals.

\subsubsection{Theories of Leadership and leadership styles}

Leadership theories- researchers had derived numerous theories before, and may emanate more theories in the future. However, leadership theories can be grouped into categories such as Suberi (2013) based leadership styles on trait, behavior and situation. Most theories on leadership are described on the "Trait, behavioral, and contingency approaches" (Mullins, 2002).

\subsubsection{Trait Leadership Theory}

Trait theory was basically rested on innate distinctiveness of a person. Leaders must have an inherent capability and personality of their parents or ancestors. This theory believes that 'leaders are born'. It emphasizes on the personal traits of the leader such as appearance, height, initiative, aggressiveness, enthusiasm, selfconfidence, drive, persistence, interpersonal skills and administrative ability (Adeyemi, 2010). This theory was one of the first studies carried out on leadership in the early $20^{\text {th }}$ century.

Nsubuga (2008) however argued that leadership that emphasized on individual personality and skills is no longer perceived as the sole determinant of a good leader. An appropriate mixture of personal behaviors is seen as an important contribution to effective leadership. Thus, the behavioral leadership theory came to an existence.

\subsubsection{Behavioral Leadership Theory}

Behavioral leadership theories stress more on leaders' behaviors in contradictory to trait theory. The first behavior leadership study was conducted at Iowa 
University where Kurt Lewin navigated a group of academics to find out leadership styles in 1939 (Clark, 1997). The team found three major leadership styles: autocratic, democratic and laissez-faire. The detail concept of these leadership styles are as follows:

\subsection{Autocratic leadership style:}

This style is also recognized as "Authoritarian leadership Style" (Cherry, 2020), and considered as "Classical Approach" (Khan et al, 2015). Such leaders monitor their followers closely, and ensure that tasks are accomplished in a given time (Mullins, 2002). Leaders who fall under this style usually control decisions with diminutive or no acceptance of contributions from their subordinates.

Decisions enforced on the team by this type of boss are neither discussed nor willingly acknowledged by their subordinates. Greenfield (2007) believed that decisions imposed on employees are non-discussed. Hoyle (2012) shared that autocratic styles can be presented in pyramid of hierarchy, leader on top and employees below. Authoritative character is main feature of autocratic leader over stakeholders. Northouse (2012) claimed that leaders in this category demonstrate that they are in command, and exert influence and control over their employees.

Autocratic leaders "Centralizes authority, dictate work methods, take unilateral decision and limit employee participation" Boje, (2000 cited in Mabuku, 2009). Oppressive leaders command their associates what to do, how to do, when to do, where to do and when to complete. So, these categories of leaders are considered very stringent. Durosaro (n.d) denoted autocratic person in charge as "Tough Battler and strict disciplinarian". They direct or threatened workers to get organizational goals achieved. Thus, the style is seen as task-oriented (Dubrin, 1998).

Shortfall of this leadership style is that it may cause hindrances to employees' creativities, and they could never be independent. They could not do a thing in devoid of guidances from leaders (Northouse, 2012). Chukwusa (2018) determined that autocratic styles avert creative ideas. Followers try to accomplish the task out of fear, and therefore the quality of tasks is compromised.

Any response or reaction gained through threat and fear remains relatively for a short term. Rahbi et al (2017) stated that dictatorial nature of authoritarian leadership style can be detrimental in the long term. Chauhan (2017) too pointed out that autocratic leadership style would be ineffective and will have negative influence as it is a short-term approach. He further linked autocratic with inefficiency and discouragement for faculties who believe in democracy. Martin (2009) supported that autocratic decision undermines work morale.

In spite of many drawbacks, such style is necessary and has numerous benefits. Tasks are usually accomplished on time by way of providing clear directives to followers. According to Nsubuga (2008) head teachers generally accentuate autocratic leadership style since it reaps results quicker as subordinates toil with compulsory pressure to meet deadlines. Decisions are top down, and hence valuable times are not wasted in lengthy and time consuming discussions. Work quality is ensured due to fear towards leaders. Autocratic is seen advantageous when swift verdict is crucial (Chukwusa, 2018). In the event that there is a major conflict amid subordinates, the leader cannot wait for collaborative decision. The leader has to decide instantly without consensus. So, this style could be favorable where situation and task mandate urgent actions. Adept, well-versed and knowledge laden must be strength of these leaders.

\subsection{Democratic leadership style}

According to Nsubuga (2008) some of the main characteristics of this leadership are transference of authority, participatory planning and mutual communication. While Oyetunji (2006) referred that the major point of focus for participative style is sharing. This leadership is also branded as "participative leadership" (Mind Tools, 2008) or "shared leadership" (Cherry, 2020) as it lets followers to partake in decision-making process. Employees are held accountable for their own decisions and actions (Avolio et al, 2009). Northouse (2012) reflected that more than controlling their employees, democratic leaders work with employees, try their best to treat everyone equally with no prejudice, and hold themselves at par with their employees. They trust their staff and consider that employees are in better position to understand the problem and reflect on it. David (2007) maintained that democratic impacts the trust levels of employees.

Employees can express their opinions, and decisions are thus common. So, employees' responsiveness to decision is definite with the enhanced motivation, high morality, improved creativity and boosted efficacy. Goleman et al (2002) accepted that democratic leader elevate subordinates' self-esteem, and organization can have positive work atmosphere.

Though democratic leaders seem most appropriate approach as mentioned by Mabuku (2009), it also has downsides such as wastage of time due to prolonged discussion. Accomplishment of task is not as effective compared to authoritarian style (Northouse, 2012). In some cases followers feel pressurized due to lack of knowledge or expertise on particular discussion. 
More shortfalls of the style are, communication failure and weak conclusion by unskilled groups, revealed Cherry (2020).

\subsection{Laissez- Faire leadership style}

This leadership style is labeled as "Nonleadership" (Northouse, 2012), "Passive Leaders" (Yang, 2015) or "No leadership" (Aydin et al, 2013). This type of leadership is characterized as least bothered of their employees and decision- making process. Greiman et al (2007) claimed such leaders relinquish responsibilities, delay decisions and fail to provide requested backing. In organizations with these types of leaders, decisions are overridden by followers. These leaders rely on subordinate's decisions irrespective of how valid the subordinates' decision is for the organization. Nsubuga (2008) noted that there is no person of authority in the organization. Manager leads the organization indirectly. Laissez-faire style tolerate leaders losing control over their subordinates. This was backed up by Ololube (2013) who stated that this style arises when the leader doesn't have appropriate control on their subordinates.

In absence of instructions from such leaders, employees are jumbled not knowing what, how, and when to proceed with the task. Working atmosphere is haphazard and indiscipline. Subsequently, it leads to unsatisfactory accomplishment. The leader provides very less control due to which staff often linger unsure of their roles and responsibilities (Rahbi et al, 2017). With no effective direction from leaders, task goes off track, missing deadlines (Malechwanzi, 2018). Enthusiastic employees become frustrated, unmotivated and disheartened whereas those lazy employees with undedicated nature may follow their leaders' "hand-off" characteristic on their responsibilities.

The laissez-faire leadership style also provides opportunities to every individual to decide on their own, and work accordingly with no intrusion from his/her leader. According to Mind Tools (2008), such leadership plays best if employees are adept, qualified, committed and selfstarter.

Autocratic, democratic and laissez-faire leadership styles are undeniably different from each other as explained. Each style has its own distinctiveness. Yet, it cannot occur disjointedly on its own; they occur in coherent from high to low leadership effect. "Laissez-faire style implies low control, autocratic style high control and democratic remains in between" emphasized Musera et al (2012).

Though there are different leadership styles, almost all leadership styles appear to imitate characteristics of these three major leadership styles; autocratic, democratic and laissez-faire.
Mgbodile (2004) specified that in spite of diverse terminologies deployed for leadership styles, in general the styles practiced by leaders are of three types- autocratic, democratic and laissez- faire.

Thereby, researcher aims to discover which of these three leadership styles (autocratic, democratic and laissez-faire) are employed by heads of the Public TTIs in Bhutan.

\section{RESEARCH METHODOLOGY}

\subsection{Design}

This study was carried out using the descriptive survey, a quantitative method. The advantages of quantitative method are numerous. It provides the breadth of coverage within short span of time. The closed-ended survey questionnaire is also easier and more convenient for respondents to answer. Further, the quantitative design does not involve direct connection between researcher and the samples. Thus, the bias was being controlled. Research data were collected from respondents via Google Form. In the current situation of global COVID 19 pandemic, medium of data collection via online Google Form was perceived the safest and viable.

\subsection{Population and Sample}

The target population was 160 staff of six public TTIs of Bhutan. Based on Krejcie and Morgans' table (1970) the sample size of 113 staff of six public TTIs is determined. Survey questionnaires were mailed to the targeted population in each institute, and aimed to collect at least the minimum set sample. Ultimately, the researcher received completed questionnaires from 122 respondents.

\subsection{Research Instruments}

Multiple choices and filling the blanks were administered to collect demographic data of participants. To identify leadership style of head of public TTIs of Bhutan, the descriptive questionnaire for quantitative data with five-point

Likert scale Leadership Styles Survey (LSS) questionnaires of Clark (1998) was modified and administered.

\subsection{Quality of the Research Instruments}

The reliability of the instrument was trial tested in one of the institutes that shared similar characteristics to sample institutes. Cronbachs' coefficient alpha was applied to ensure reliability of the questionnaires. The questionnaires scored Cronbachs' alpha coefficient of 0.90 meeting the required Cronbachs' coefficient alpha of at least 0.65 . 


\subsection{Research Ethics and Data Collection}

Official request letters were sent to all the heads of the sample TTIs for granting access to research survey data collection. Consent note along with the questionnaires were mailed to all participants via Google Form. Participants were also contacted via telephone calls individually to assured that responses will be treated with confidentiality, and that the participants will remain anonymous though out. The questionnaires administered did not require participant's name or other form of identity description.

\subsection{Data Analysis}

Data collected were tabulated in the Statistical Package for the Social Sciences (SPSS). Descriptive statistics like mean, standard deviation, and percentage were used to analyze data.

\section{RESULT}

\subsection{Demographic data of participants}

$59 \%$ of respondents were male and $41 \%$ female. $57.4 \%$ had Diploma qualification, followed by $21.3 \%$ Bachelor Degree. Only $1.6 \%$ respondents had Master Degree. Majority of respondents $(47.5 \%)$ were in $31-40$ years age range group. Only $14 \%$ of respondents was in the age range of 40 plus. The oldest respondent was 54 years old and the youngest was 23 years old. The mean age was 34.3. Majority of respondents $(49.2 \%)$ had job experiences of $1-10$ years while only $12.3 \%$ had 20 plus years. The job experiences of respondents ranged from 2 to 36 years with mean experience of 11years.

\subsection{Staff's perception on their institute heads leadership styles}

Table 4. 1 Staff's perception on Autocratic Leadership style

$(n=122)$

\begin{tabular}{|c|c|c|c|}
\hline Statements & $\overline{\mathbf{x}}$ & S. D & Perception Level \\
\hline 1. Always retains the final decision-making authority. & 3.67 & .857 & High \\
\hline 2. Does not consider suggestions made by us. & 2.84 & 1.206 & Moderate \\
\hline 3. Tells staff what has to be done and how to do it. & 3.81 & .894 & High \\
\hline $\begin{array}{l}\text { 4. Tells us not to ever do that again and make a note of it when we make } \\
\text { mistake. }\end{array}$ & 3.66 & .878 & High \\
\hline $\begin{array}{l}\text { 5. Does not allow new staffs to make any decision unless it is approved by } \\
\text { him/her. }\end{array}$ & 2.93 & 1.148 & Moderate \\
\hline $\begin{array}{l}\text { 6. Tells us if a procedure is not working correctly and establish a new one when } \\
\text { something goes wrong. }\end{array}$ & 3.65 & .978 & High \\
\hline 7. Closely monitors us to ensure that we are performing correctly. & 3.63 & 1.022 & High \\
\hline 8. Likes the power that his/her leadership position holds over us. & 3.45 & 1.005 & High \\
\hline $\begin{array}{l}\text { 9. Directs or threatens with punishment in order to get us to achieve the } \\
\text { organizational objectives. } \\
\text { 10. Does not believe in our creativity and ingenuity to solve organizational } \\
\text { problems. }\end{array}$ & 2.46 & 1.200 & $\begin{array}{c}\text { Low } \\
\text { Moderate }\end{array}$ \\
\hline
\end{tabular}

Note: 1.00-1.80= Lowest, 1.81-2.60= Low, 2.61-3.40=Moderate, 3.41-4.20= High, 4.21-5.00= Highest

As seen in table 4.1, item 3 "Tells staff what has to be done and how to do it" received the high level of staffs' perception with the mean score of 3.81. However, for item 9 that stated "Directs or threatens with punishment in order to get us to achieve the organizational objectives." was rated the least with the mean score of 2.46. 


\begin{tabular}{|c|c|c|c|}
\hline Statements & $\overline{\mathbf{x}}$ & S. D & Perception Level \\
\hline $\begin{array}{l}\text { 1. Always tries to include one or more of us in determining what to do and } \\
\text { how to do it. However, he or she maintains the final decision-making } \\
\text { authority. }\end{array}$ & 3.86 & .816 & High \\
\hline 2. Asks for our ideas and input on upcoming plans and projects. & 3.94 & .998 & High \\
\hline $\begin{array}{l}\text { 3. Calls a meeting to get staff advice when things go wrong and need to } \\
\text { create a strategy to keep a project or process running on schedule. }\end{array}$ & 3.89 & .964 & High \\
\hline $\begin{array}{l}\text { 4. Creates an environment where we are given an ownership of the project } \\
\text { and allow us to participate in the decision-making process. }\end{array}$ & 3.68 & .973 & High \\
\hline $\begin{array}{l}\text { 5. Asks us for our vision of where we see our jobs going and use it for } \\
\text { wherever appropriate. }\end{array}$ & 3.48 & .938 & High \\
\hline 6. Allows us to set priorities with his/her guidance. & 3.45 & .882 & High \\
\hline $\begin{array}{l}\text { 7. Works with us to resolve the differences when there are differences in role } \\
\text { expectations. }\end{array}$ & 3.47 & .946 & High \\
\hline 8. Exercises his/her leadership power to help us grow professionally. & 3.54 & 1.014 & High \\
\hline 9. Allows us to exercise self-direction if we are committed to the objectives. & 3.56 & .891 & High \\
\hline 10. Ensures our job security & 3.69 & .854 & High \\
\hline
\end{tabular}

Note: $1.00-1.80=$ Lowest, 1.81-2.60= Low, 2.61-3.40=Moderate, 3.41-4.20= High, 4.21-5.00= Highest

Table 4.2 portrays with all items rated at high level. Item 2 "Asks for our ideas and input on upcoming plans and projects' received the highest perception with mean score of 3.94. While item 6 "Allows us to set priorities with his/her guidance" was perceived the least with the mean score of 3.45 .

Table 4. 3 Staff's perception on Laissez-faire Leadership style

$(n=122)$

\begin{tabular}{|c|c|c|c|}
\hline Statements & $\overline{\mathbf{x}}$ & S. D & Perception Level \\
\hline 1. Always prefers voting system whenever a major decision has to be made. & 3.80 & 1.103 & High \\
\hline $\begin{array}{l}\text { 2. Always seeks the approval of each or majority of us for a major decision to } \\
\text { pass in the institute. }\end{array}$ & 3.81 & .912 & High \\
\hline $\begin{array}{l}\text { 3. Sends email, text message, or voice mail to get information out, rarely any } \\
\text { meeting is called. We are then expected to act upon the information. }\end{array}$ & 3.80 & 1.044 & High \\
\hline 4. Allows us to determine what needs to be done and how to do it. & 3.64 & .853 & High \\
\hline 5. Allows us to carry out the decisions to do our job. & 3.63 & .874 & High \\
\hline 6. Delegates tasks in order to implement a new procedure or process & 3.62 & .866 & High \\
\hline 7. Responsibility to define our job is left upon us all the time. & 3.32 & .929 & Moderate \\
\hline
\end{tabular}


\begin{tabular}{|l|l|c|c|c|} 
8. Shares his/her leadership power with us. & 3.52 & 1.085 & \multicolumn{2}{c|}{ High } \\
9. Always leave on us to determine the organization's objectives & 3.11 & 1.003 & moderate \\
10. Knows that we can lead ourselves just as well as he/she can & 3.52 & .855 & High \\
\hline
\end{tabular}

Note: $1.00-1.80=$ Lowest, 1.81-2.60= Low, 2.61-3.40=Moderate, 3.41-4.20= High, 4.21-5.00= Highest

As shown in table 4.3, item 2 "Always seeks the approval of each or majority of us for a major decision to pass in the institute." was rated the high among all items with mean score of 3.81. Item 9 "Always leave on us to determine the organization objective" received the least perception with the mean score of 3.11 .

Table 4.4 Staff's perception on their institute heads leadership styles (summarized) ( $n=122$ )

\begin{tabular}{lccc}
\hline Leadership Styles & $\overline{\mathbf{x}}$ & S. D & Perception level \\
\hline Autocratic Leadership & 3.27 & 1.03 & Moderate \\
Democratic Leadership & 3.66 & 0.93 & High \\
Laissez-Faire Leadership & 3.58 & 0.95 & High \\
\hline
\end{tabular}

Note: $1.00-1.80=$ Lowest, 1.81-2.60= Low, 2.61-3.40=Moderate, 3.41-4.20= High, 4.21-5.00= Highest

The result in table 4.4 indicates that the democratic leadership style had the greatest staff's perception level with the mean score of 3.66, followed by laissez - faire leadership style yet at high level with the mean score of 3.58. Autocratic leadership style was perceived the least at moderate level with the mean score of 3.27.

\section{DISCUSSION}

The analysis of data showed that the heads of public TTIs exhibited Democratic Leadership Styles more than Autocratic and Laissez- faire leadership styles. This is in concurrence to the findings of Hwa (2008), Adeyemi (2010), Honari et al (2011), and Razak et al (2015), who all found that democratic leadership styles were most popular leadership styles practiced by heads of organizations, and most preferred by participants. Honari et al (2011) found that group member under democratic leaders portrays more creativity, cooperation and better performance. Khajeh (2018) found that democratic styles enhance employees' creative and decision-making skills. Dolly and Nonyelum (2018) viewed democratic leaders with positive effect on employee's job satisfaction and performance. Wangmo (2013) associated democratic leaders with better influence on management of organization. She further associated democratic styles with upliftment of staff's trust, commitment, work morale and efficacy. Employees' job satisfaction, improved performance and better management, creativity and decision-making skills, positive influences and belief, cooperation and commitment, and enhanced work morale and efficacy are key factors towards achievement of organizational goals.

In the study the staff's perception level on democratic leadership scored high with mean score of 3.66.
It was closely followed by laissez- faire with mean score of 3.58. The high score on laissez-faire styles was surprising, though not totally unexpected as it resonant the findings of Razak et al (2015) who found out that popularity of democratic leadership styles was closely followed by laissez-faire leadership styles. Some of the respondents in this study were very matured and had number of years of experience working in the institutes. This could have let them take ownership and more responsibilities in their institutes.

On the perception of laissez-faire leadership style, staff members rated very high on seeking the approval of each other or majority of staff for major decisions. Since the heads of TVET institute of this study research sites were new on the job (most of them had 4 years experience as heads of TTIs), they must have had to rely more on technical staff members' expertise while discussing on technical programs.

Autocratic style was perceived at moderate level. Item 3 on the Staff's perception on Autocratic Leadership style "Tells staff what has to be done and how to do it" was rated the highest with mean score of 3.81 . Since $38.5 \%$ of staff respondents were young and fell in age range of 2030 , and $49.2 \%$ had job experience of less than 10 years. They needed close direction and supervision. This has the support of Nsubuga (2008) who determined that authoritative fits well with new recruits, younger and less 
experienced staff, where they were needed to be controlled and guided vigorously.

In general, the result confirmed the work of Nebojsa et al (2012), who exposed that heads or the principals of institutes applied all three classical leadership styles based on situations. Vroom and Jago (1988) asserted that there are no single leadership styles that fit all conditions. It is a blunder to adopt lone style in all the circumstances (Khan et al, 2015). It will not be practical to apply democratic leadership style while situation asks for assertive tactic (Nzembe, 2017). Various situations mandate diverse kinds of leadership styles. Leaders ought to perform with requirement of specific circumstances (Veliu et al, 2017). Thus, the aim must be to discover situational styles (Schramm, 2005).

\section{CONCLUSION AND RECOMMENDATION}

The findings established that the heads in public TTIs portray all three leadership styles. Democratic leadership style was the most prevalent, and autocratic the least dominant one. Different state of affairs demands different leadership style, and it would be imprudent to apply one style while scenarios call for others. If the team members are unorganized, ill-disciplined, and the circumstances calls for quick decision, autocratic leadership style is more effective. For organized and knowledgeable group, democratic style is preferred one. For matured, well experienced, committed, punctual and dedicated group, laissez-faire is best suited. It is crucial that heads of the institutions are skilled with various leadership styles to cope with all situations and steer organizations harmoniously for better performance.

Therefore, this study recommended combination of all three leadership styles in the TTIs. In-service training for heads of institutes, specifically focusing on courses/programs offered in his/her institute is deemed necessary. It could allow the heads of the TTIs to make better decisions without having to rely much on trade experts.

Researcher recommends future researchers to employ mixed methods for in-depth result to enhance the current study. Studies applying various variables such as, management of institute, staff's performance and job satisfaction among others that might have correlation with leadership styles are suggested. Replicating the same study on heads of the private TTIs in Bhutan could be explored by researchers.

\section{DEFINITION OF THE KEY TERMS}

Leadership Style refers to the way leaders behave in influencing group members toward attainment of organizational goals with healthy work environment.

Autocratic leaders refer to leaders who dictate their decision on their group without their consensus.

Democratic leaders refer to leaders who capitalize the knowledge, skills and talents of their group members with involvement in decision making process.

Laissez - faire leaders refer to leaders who provide utter freedom to their group members leaving decision making process and other tasks to be accomplished on their will.

Public institute refer to government owned technical institutes that provide vocational training to school leavers and unemployed youth.

Head of Institute refers to either principal or training director that leads public institute in Bhutan.

\section{REFERENCES}

[1] Adeyemi, T. (2010). Principals' leadership styles and teachers' job performance in senior secondary schools in Ondo. Nigeria: University of Ado-Ekiti.

[2] AES. (2012). Annual Education Statistic. Thimphu Bhutan: Policy Planning and Division.

[3] Ahmad, H. (2015). Leadership in TVET for the $21^{\text {st }}$ Century: Challenges, Roles and Characteristics. Social and Behavioral Science. DOI: 10.1016/j.sbspro.2015.06.446

[4] Avolio, B. Walumbwa, F. \& Weber, T.J. (2009). Leadership Current Theories, Research and Future directions. Annual Review of Psychology, 60,421-449

[5] Aydin, A. et al (2013). The effect of School Principals' Leadership Styles on Teachers Organizational Commitment and Job Satisfaction. Educational Sciences: Theory \& Practice, 13(2),806-811

[6] Best, J. (1981). Research in Education (4 ${ }^{\text {th }}$ ed.). Jersey, New York: Prentice Hall, Inc.

[7] Brennan, P. (2014). Raising the Quality and Image of TVET: Lower- Level Training or Motor for inclusive and sustainable growth? UNESCO IBE 2014, 183-195

[8] Cherry, K. (2020). Leadership Styles. www.psychology.about.com/od/leadership/a/Leadstyles.ht $\underline{\mathrm{m}}$.

[9] Chua et al (2018). Leadership style and its impact on employee performance. International Journal of Accounting \& Business Management, 6(1). DOI: 10.24924/ijabm/2018.04/v6.iss1.80.94

[10] Chuahan, R.K. (2017). Perception and Practices of Academic leadership in Technical schools. Journal of Training and Development, volume 3 DOI: http://dx.doi.org/10.3126/jtd.v3i0.18227

[11] Chukwusa, J. (2018). Autocratic Leadership Style: Obstacle to Success in Academic Libraries. Library Philosophy and Practice (e-journal).2019 http://digitalcommons.unl.edu/libphilprac/2019 
[12] Clark, D. (1997). Leadership styles. Retrieved from www.nwlink.com on May 5, 2013

[13] Clark, D. (1998). Leadership Style survey. Retrieved from www.nwlink.com.on $15^{\text {th }}$ February 2013

[14] Cronbach, L. J. (1970). Essentials of Psychological Testing. New York: Harper \& Row.

[15] David, T. et al (2007). Building Trust among Educational Stakeholders Through Participatory School Administration: Leadership and Management. Management in Education, 21(1), 15-22.

[16] Dolly, K.C\& Nonyelum, O.P (2018). Impact of democratic Leadership on Job Performance of Subordinates in academic Libraries in Port Harcourt, Rivers State, Nigeria. International journal of Research-Granthaalayah,6(10). DOI: 10.5281/zenodo.1486229

[17] Dubrin, A. (1998). In Leadership:Finding,Practice and Skills (2nd ed.).

[18] Durosaro, D. (n.d.). Management Functions, Principals and Leadership Styles in Kwara State Public Primary School.

[19] Goleman,D.Boyatzis,R \& McKee,A. (2002). The New Leadership. London: Little Brown.

[20] Greenfield, D. (2007). The enactment of dynamic Leadership. Leadership in Health services,20(3),159-168

[21] Greiman, B.C et al (2007). Preferred leadership Style of Agricultural Education Teachers: An Expression of Epistemological Beliefs about Youth Leadership development. Journal of Agricultural Education, 48(4), 93105. DOI: $10.5032 /$ jae.2007.04093

[22] Honari, H., et al. (2011). The relationship Between school Principals' Leadership Styles and Physical Education Teachers' Efficiency.

[23] Hoyle, J.R. (2012). Encyclopedia of Educational Leadership and administration. Ed. Thousand Oaks, CA: SAGE Reference online.

http://www.stydysites.sagepub.com/northouse6e/study/mat erials/.../reference4.1.pdf

[24] Hwa, C. (2008). The Impact of Principals Transformational Leadership Styles on Teachers Job Satisfaction.

[25] Kedir, K. \& Geleta, A. (2017). Leading Educational Change: The practices of Transformational Leadership in the Ethiopian Technical Vocational and Training (TVET) Institutions. International Journal of Vocational and Technical Education,9(5). DOI: 10.5897/IJVTE2017.0233

[26] Khajeh. (2018). Impact of Leadership Styles on Organizational Performance. Journal of Human Resources Management Research. DOI: 10.5171/2018.687849

[27] Khan, M.S. (2015). The Styles of Leadership: A Critical Review. Public Policy and Administration Research. 5(3). www.iiste.org

[28] KhataJabor,M. et al (2012). Sustainable Leadership for Technical and Vocational Education and Training in Developing Nations. International Journal of scientific and Research Publication. 2(8). www.ijsrp.org

[29] Kim, V. (2010). Teachers' Perception on Communication Styles and Leadership Behaviors of Private School Principals in Nakornpathom Educational area @, Thailand. 1-174.
[30] Krejcie, R. V, \& Morgan, D. W. (1970). Determining Sample Size for Research Activities. Journal of Educational Psychological Measurement, 607-610.

[31] Kusin, S.H. A. (2015). Leadership Style of Lecturer Influence on Academic Performance of TVET students. Journal of Resources Development and Management

[32] Lucas B.Ojo \& David A.Olaniyan. (2008). Leadership Roles of School Administrators and Challenges Ahead in Post- Primary Institutions in Nigeria. European Journal of Scientific Research, 24(2), 172-178.

[33] Mabuku, R. (2009). Democratic Leadership and Management Practices in a Rural Namibian Secondary school.

[34] Malechwanzi. (2018). The Impact of Leadership on Learning Outcomes: A study on Effective Leadership Styles for Principals in Vocational Colleges.

DOI: 10.4018/978-1-5225-5858-3-ch015

[35] Martin G. Kocher, Ganna,P \& Mattias, S. (2009). OtherRegarding Preferences and Leadership Styles. IZA.

[36] Mind Tools. (2008). Leadershipstyles: Using the right one for your Situation. Retrieved from http://www.mindtools.com/pages/article/newLDR-84.htm.

[37] Mgbodile, T.O. (2004). Fundamental in Educational Administration and Planning. Magnet Business Enterprise: Enugu

[38] MoLHR (2016). TVET Blueprint 2016-2026, Institutional Strengthening for Skill Development, RGoB

[39] MoLHR (2020). TVET Statistics of Bhutan, In the Quest for Transforming TVET through Data-Informed Approach. ISBN: 978-99936-59-59-4

[40] MoLHR (2020). TVET Graduate Study Bhutan, MultiCohort Online Tracer Survey Report of TTI and IZC Graduates. ISBN: 978-99936-59-60-0

[41] Mullins, J. (2002). Management and Organizational Behaviors (sixth ed.). Italy: Lombarda Rotolito.

[42] Musera Geoffrey, Achoka J.K.S \& Mugasia E. (2012). Perception of Secondary School Teachers on the Principals' Leadership Atyles in School Management in Kakamega Central district, Kenya. International Journal of Humanities and Social Science, 2(6).

[43] Nebojsa Pavlovic, Milka Oljaca \& Svetlana Kostovic. (2012). Integration of Leadership styles of School Director. Academic Journal, 7(1), 31-35.

[44] Northhouse, P. (2007). Leadership Theory and Practice. Thousand Oaks,London,New Delhi,USA,UK and India: SAGE Publications, Inc.

[45] Northhouse, P. (2012). Introduction to Leadership (Second ed.). India, Singapore,London: SAGE Publications, Inc.

[46] Nsubuga, Y. (2008). Analysis of Leadership and School Performance of Secondary Schoolin Uganda.

[47] Nzembe, A. (2017). Lecturers' Perception of Leadership Traits which Promote Motivation in South African Technical and Vocational, Education and Training (TVET) College. Academic Journal of Interdisciplinary Studies,6(2). Doi:10.1515/ajis-2017-0006

[48] Ololube, N.P. (2013). Educational Management, Planning and Supervision: Model for Effective implementation. Owerri: Spring Field Publishers. 
[49] Oyetunji. (2006). The Relationship Between Leadership Styles and School Climate in Botswana Secondary Schools.

[50] Popa, B.M. (2012). The relation Between Leadership Effectiveness and Organizational Performance. Journal of Defense Resources Management, 3(1), 123-127

[51] Rahbi, D.A. et al (2017). The Effects of Leadership Styles on Team Motivation. Academy of Strategic Management Journal, 16(2).

[52] Razak, A.B. A., Nur et al (2015). Leadership Styles of Lecturer's Technical and Vocational in Teaching and Learning. Journal of Education and Practice. 6(13). ISSN 2222-288X(Online)

[53] RCSC. (2012). Bhutan Civil Service Rules and regulations.

[54] Rost, J. C. (1991). Leadership for $21^{\text {st }}$ Century. Greenwood Publishing group

[55] Schramm, F. (2005). Open and Closed Organization. International Human Resource Management. http://www.hrnetwork.hu/szolgaltatasok/open_andclosed organizations.pdf

[56] Stogdill, R. (1974). Handbook of Leadership: A survey of theory and the research. New York: Free Press.

[57] Suberi, A.A.B.M. (2013). Review on leadership Style among TVET Lecturers. International Journal of Science and Research, 4(5). www.ijsr.net

[58] Veliu, L. et al (2017). The influence of Leadership Styles on Employees Performance. Journal of Management, 31(2),59-69. ISSN 1648-7974

[59] Vroom,V.H \& Jago,A.G. (1988). The New Leadership management: Participation in organization. New Jersey: Prentice hall.

[60] Wangmo, S. (2013). Influence of Principals' Leadership Styles on School Management of the Middle Secondary Schools in Thimphu, Bhutan. Bangkok: Mahidol University

[61] Yang, I. (2015). Positive Effects of Laissez-faire Leadership: Conceptual Exploration. Journal of Management Development, 34(10),1246-1261. 